University of Nebraska - Lincoln DigitalCommons@University of Nebraska - Lincoln

2019

Usage of Library websites in promoting Academic Library services: A survey with special reference to the selected college Libraries of Upper Assam.

Anurag Borpatra Gohain

anuragborpatra@dibru.ac.in

Follow this and additional works at: https://digitalcommons.unl.edu/libphilprac

Part of the Library and Information Science Commons

Borpatra Gohain, Anurag, "Usage of Library websites in promoting Academic Library services: A survey with special reference to the selected college Libraries of Upper Assam." (2019). Library Philosophy and Practice (e-journal). 2655.

https://digitalcommons.unl.edu/libphilprac/2655 


\title{
Usage of Library websites in promoting Academic Library services: A survey with special reference to the selected college Libraries of Upper Assam.
}

\author{
Anurag Borpatra Gohain, Assistant Professor, CLISS, Dibrugarh University,Assam. \\ anuragborpatra@dibru.ac.in
}

Prasanna Kumar Konch, MLIS Student, CLISS, Dibrugarh University,Assam.

\begin{abstract}
This paper tries to portrait the usage of library website as a tool for promotion of library services in the selected college libraries affiliated to Dibrugarh University. A pre-structured questionnaire has been used for the collection of primary data under the scope of the study. A total 12 colleges has been selected randomly for the study. This study helps in identifying the current status of library websites \& ICT infrastructure as a whole in the colleges of Upper Assam.
\end{abstract}

Keywords : Library Website, ICT, College Library,CMS,OPAC,Web-OPAC.

\section{INTRODUCTION}

As the constituents of the information age we are witnessing the role of Information and Communication Technology (ICT) in providing access to information as well as disseminate the information to the user community. The Internet technology is a very effective to access and disseminate information which provides access to an endless variety of information including news, research, healthcare information, crime statistics, multimedia etc. Libraries have prolonged used technology to deliver and improve access to their resources and services. From the earliest automated circulation systems and catalogues, to the rise of web-based resources, libraries have fervently used technology for more effective conveyance of information resources to their clienteles. Since the decade of 90's libraries have accustomed to the use of the web to deliver content including access to e-resources, information about specific collections and services. Libraries often use the web for services as e-reference via e-mail, chat and instant messaging systems. In this $21^{\text {st }}$ century the development in the field of ICT is very fast and ever increasing. Information and communication technology change the scenario of conventional library to the virtual one. The library has no more the traditional concept of a place where books are stored on the shelves. The current digital revolution especially internet and website technology integrated with 
treasure of information has emerged in the past few years, as an indispensable tool for people in pursuit of knowledge and information. The benefits and opportunities, the internet is offering today, have been widely recognised and appreciated by the citizens. Web technology has been used in library field for creation of library home pages or as gateways to facilitate the information about the library. Library home page provides a platform to proliferate various services and facilities to the intellectual community worldwide. The homepages of library used often as an interface for providing information about the web based scholarly resources it holds. As the library professional we observe that the library websites should acts as the mirror of the library, and the information provided in the library to their users. Librarians are to be responsible for the designing the content of the library website.

\section{LITERATURE REVIEW}

Kumar (2017) describes the impact of ICT based products and services on the library users with a special reference to academic library. He emphasized the need and advantage of marketing e-resources through library websites, blogs etc. Manjunath (2016) analysed the contents of the websites of eight special libraries based on Bengaluru. Special emphasis is given on library collection, library services, availability of e-resources, domain \& display recognition, links, search \& retrieval interface. Kaushik (2015) studies on the features of library websites of 28 NITs in India. The study reveals that most of the libraries facilitate conventional services through their websites; failing to incorporate cutting edge technologies like web 2.0 facility, cloud based services. Pareek and Gupta (2012) studies library website as promotional tool for information resources in some selected University libraries of Rajasthan focusing on library services \& e-resources. Konnur and Rajani et al (2010) focuses on the currency, accuracy and relevance of the information contents provided in library websites of Bangalore. Kaur and Singh (2010) found that reference services are highly demanded on web platform. Shukla and Tripathi (2010) examined the content status on websites of libraries of Indian academic institutions to measure overall website performance. Performance calculation was done through criteria which would be helpful to the library webmasters to improve their content awareness status of their library websites.

\section{OBJECTIVES OF THE STUDY}

The primary aim of the study was to investigate the usages and effectiveness of the library website to promote the academic library services, especially in the college libraries of Assam. The main objectives of the study are:

1. Examine the usage of Library websites/webpage for providing Library services.

2. Find out the effectiveness of Library website for providing better Library services.

3. To know about the services provide for promoting academic Library services. 


\section{SCOPE AND COVERAGE OF THE STUDY}

Library website is like a virtual guide of the physical facilities including collections, services and infrastructure available in the library. Website is the best source for information for the outsider. They are the mirror of the library. The preliminary idea about the library can be achieved from the website. The present study is mainly confined to the usage of library websites in promoting academic library services. Each of the colleges has a library but maximum of the libraries don't have a separate library website. They have library webpage which is amalgamated to college website. Selected college libraries under the scope of study are as follows:

1. Central Library, Madhabdev College

2. Central Library,Dhakuwakhana College

3. Mohan Chandra Roy Library, Lakhimpur Kendra Mahavidyalaya

4. Rd. B.S. Granthagar, North Lakhimpur College

5. Central Library,Dhakuwakhana College

6. Central Library, Moridhal College

7. Central Library, Debraj Roy College

8. Central Library, Gogamukh College

9. Maskhuwa Degree College Library

10. Central Library, MDKG College

11. Central Library, Dhemaji Commerce College

12. Central Library, Dhemaji College. 


\section{DATA ANALYSIS AND INTERPRETATION}

(From the stance of the Librarian from the surveyed colleges)

Table 1: Daily user statistics

\begin{tabular}{|c|c|c|c|c|}
\hline \multirow[t]{2}{*}{ SI.No } & \multirow[t]{2}{*}{ Name of the Library } & \multirow{2}{*}{$\begin{array}{l}\text { Total registered } \\
\text { user }\end{array}$} & \multicolumn{2}{|c|}{ Frequency } \\
\hline & & & No of daily user & $\%$ \\
\hline 1 & $\begin{array}{l}\text { Central Library, } \\
\text { Madhabdev College }\end{array}$ & 675 & 150 & 22.22 \\
\hline 2 & $\begin{array}{l}\text { Central Library, } \\
\text { Dhakuakhana College }\end{array}$ & 1100 & 80 & 7.27 \\
\hline 3 & $\begin{array}{l}\text { Central Library, } \\
\text { Dhemaji College }\end{array}$ & 1200 & 100 & 8.33 \\
\hline 4 & $\begin{array}{l}\text { Mohan Chandra Roy Library, } \\
\text { Lakhimpur Kendriya } \\
\text { Mahavidyalaya }\end{array}$ & 927 & 150 & 16.18 \\
\hline 5 & $\begin{array}{l}\text { Central Library, } \\
\text { Moridhal College }\end{array}$ & 1253 & 89 & 7.10 \\
\hline 6 & $\begin{array}{l}\text { Central Library, Gogamukh } \\
\text { College }\end{array}$ & 1200 & 60 & 5.00 \\
\hline 7 & $\begin{array}{l}\text { Central Library, } \\
\text { D.R.College }\end{array}$ & 1300 & 165 & 12.69 \\
\hline 8 & $\begin{array}{l}\text { Maskhowa Degree College } \\
\text { Library }\end{array}$ & 1300 & 50 & 3.84 \\
\hline 9 & $\begin{array}{l}\text { Central Library ,Dhemaji } \\
\text { Commerce College }\end{array}$ & 1590 & 60 & 3.77 \\
\hline 10 & $\begin{array}{l}\text { Central Library, MDKG } \\
\text { College }\end{array}$ & 1800 & 60 & 3.33 \\
\hline 11 & Central Library, Dibru College & 1600 & 70 & 4.37 \\
\hline 12 & $\begin{array}{l}\text { Dr.B.S.Granthagar, } \\
\text { N.L.College }\end{array}$ & 4200 & 150 & 3.57 \\
\hline
\end{tabular}

Daily footfalls: Table 1 shows the daily user statistics of the surveyed college library. The figure shows that number of daily user in the library of Madhabdev College is highest (22.22\%) followed by Library of Lakhimpur Kendriya Mahavidyalaya (16.18\%). But in some colleges very less number of users visited to the library.

During the survey period some facts reveals that several users are mainly accustomed to the issue and return the books, reading the magazines and newspaper but they were not aware about the library website and the effectiveness of the library website. 


\section{Status of library website}

Library Website: Table 2: From the survey it is clearly shows that $67 \%$ (8 Libraries) of surveyed college library has a separate Library webpage or website. In the website they provides the basic information about the library services, timing, staff details, collections, functions and short description about the library. 33\% (4 Libraries) of colleges don't have library website due to the lack of proper ICT infrastructure to develop a website. But some colleges are taking initiative to develop library website.

Table 2: Status of Library Website

\begin{tabular}{|c|c|c|c|}
\hline \multirow[t]{2}{*}{ Sl. No } & \multirow[t]{2}{*}{ Name of the College } & \multicolumn{2}{|c|}{ Website } \\
\hline & & Yes & No \\
\hline 1 & Madhabdev College & $\checkmark$ & $x$ \\
\hline 2 & Dhakuakhana College & $\checkmark$ & $x$ \\
\hline 3 & Dhemaji College & $\times$ & $\checkmark$ \\
\hline 4 & Lakhimpur Kendriya Mahavidayalaya & $x$ & $\checkmark$ \\
\hline 5 & Moridhal College & $\checkmark$ & $x$ \\
\hline 6 & Gogamukh College & $x$ & $\checkmark$ \\
\hline 7 & Debraj Roy College & $\checkmark$ & $x$ \\
\hline 8 & Maskhowa Degree College & $x$ & $\checkmark$ \\
\hline 9 & Dhemaji Commerce College & $\checkmark$ & $x$ \\
\hline 10 & M.D.K.G. College & $\checkmark$ & $x$ \\
\hline 11 & Dibru College & $\checkmark$ & $x$ \\
\hline 12 & North Lakhimpur College (Autonomous) & $\checkmark$ & $x$ \\
\hline
\end{tabular}

\section{Web OPAC for Information Retrieval}

Web-OPAC: Table 3 is an illustration of the college libraries using Web-OPAC as a library resource retrieval tool. In some colleges it is found that they use library Web-OPAC as an alternative to library website. It provides the structured webpage to access the WebOPAC as well as the library services and information. It provide library timing, library 
description, e-resource link, Location, membership, Institutional Repository, library facilities and Virtual tour of library etc.

Table 3: Use of Web-OPAC

\begin{tabular}{|c|c|c|c|}
\hline \multirow[t]{2}{*}{ Sl. No } & \multirow[t]{2}{*}{ Name of the College } & \multicolumn{2}{|c|}{ Use of Web-OPAC } \\
\hline & & Yes & No \\
\hline 1 & Madhabdev College & & $\checkmark$ \\
\hline 2 & Dhakuakhana College & & $\checkmark$ \\
\hline 3 & Dhemaji College & $\checkmark$ & \\
\hline 4 & Lakhimpur Kendriya Mahavidayalaya & $\checkmark$ & \\
\hline 5 & Moridhal College & & $\checkmark$ \\
\hline 6 & Gogamukh College & $\checkmark$ & \\
\hline 7 & Debraj Roy College & & $\checkmark$ \\
\hline 8 & Maskhowa Degree College & & $\checkmark$ \\
\hline 9 & Dhemaji Commerce College & & $\checkmark$ \\
\hline 10 & M.D.K.G. College & $\checkmark$ & \\
\hline 11 & Dibru College & $\checkmark$ & \\
\hline 12 & North Lakhimpur College (Autonomous) & $\boldsymbol{\nu}$ & \\
\hline
\end{tabular}

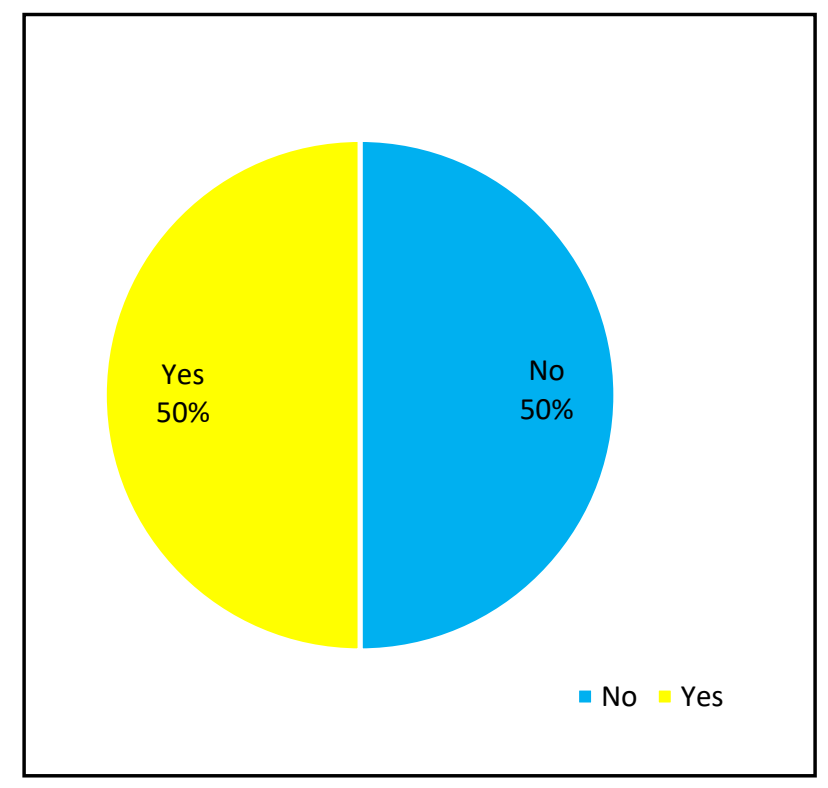

Figure 1 display the libraries provide the online catalogue search facility in library website. Online catalogue is providing through the Web-OPAC service. The survey reveals that $50 \%$ (6) colleges have provided online catalogue service to the user in website. $50 \%$ (6) numbers of college could not provide online library catalogue they only provide OPAC service in library campus. 


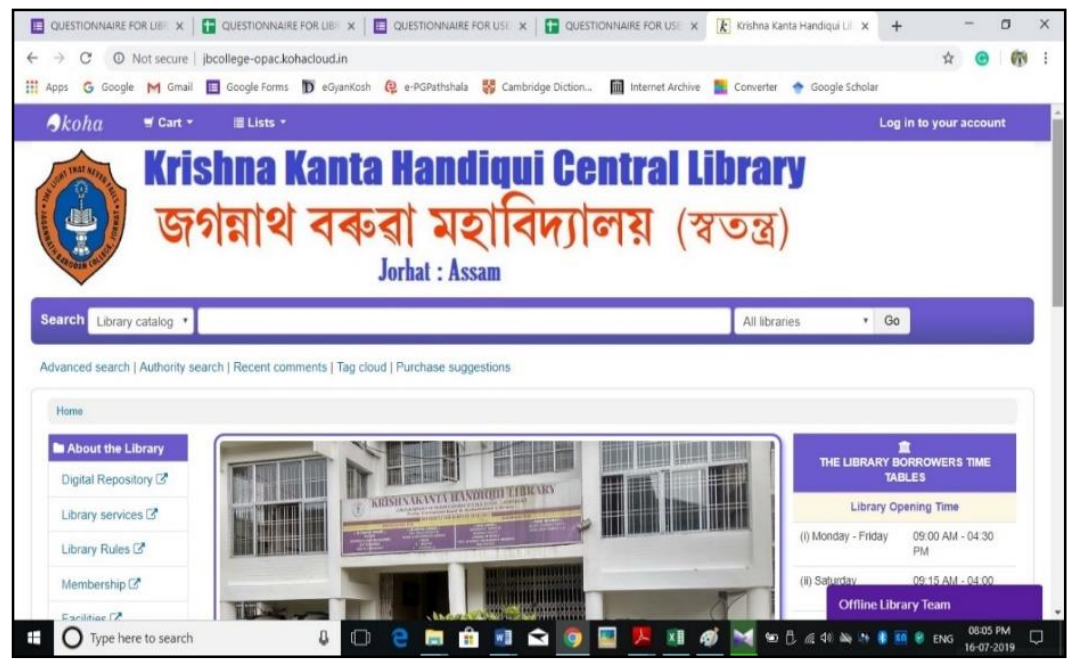

server which is accessible from outside the campus.
Figure 1: Use of

Web OPAC

Figure 2 is an example of Web-OPAC developed through integrated library management software KOHA. It is hosted in cloud

Figure 2: Krishna Kanta Handiqui Central Library Web-OPAC

(Source: http://jbcollege-opac.kohacloud.in/)

Table 4: Usage of CMS

\begin{tabular}{|c|c|c|c|c|c|c|c|}
\hline \multirow{2}{*}{$\begin{array}{l}\text { Sl. } \\
\text { No }\end{array}$} & \multirow[t]{2}{*}{ Name of the College } & \multicolumn{6}{|c|}{ Usage of CMS } \\
\hline & & Joomla & Drupal & Wordpress & Blogspot & Wix & Other \\
\hline 1 & Madhabdev College & $x$ & $x$ & $\times$ & $x$ & $x$ & \\
\hline 2 & Dhakuakhana College & $x$ & $x$ & $x$ & $x$ & $x$ & $\checkmark$ \\
\hline 3 & Dhemaji College & $x$ & $x$ & $x$ & $x$ & $\times$ & $\checkmark$ \\
\hline 4 & $\begin{array}{l}\text { Lakhimpur Kendriya } \\
\text { Mahavidayalaya }\end{array}$ & $x$ & $x$ & $x$ & $x$ & $x$ & $\checkmark$ \\
\hline 5 & Moridhal College & $x$ & $\times$ & $x$ & $x$ & $\times$ & $\checkmark$ \\
\hline 6 & Gogamukh College & $x$ & $x$ & $x$ & $x$ & $x$ & $\checkmark$ \\
\hline 7 & Debraj Roy College & $x$ & $x$ & $\times$ & $x$ & $x$ & $\checkmark$ \\
\hline 8 & Maskhowa Degree College & $x$ & $x$ & $x$ & $x$ & $x$ & $x$ \\
\hline 9 & Dhemaji Commerce College & $\times$ & $\times$ & $\times$ & $x$ & $x$ & $\checkmark$ \\
\hline 10 & M.D.K.G. College & $x$ & $x$ & $x$ & $x$ & $\checkmark$ & $x$ \\
\hline 11 & Dibru College & $x$ & $x$ & $\times$ & $x$ & $x$ & $\checkmark$ \\
\hline 12 & North Lakhimpur College & $x$ & $x$ & $\times$ & $x$ & $\times$ & $\checkmark$ \\
\hline
\end{tabular}




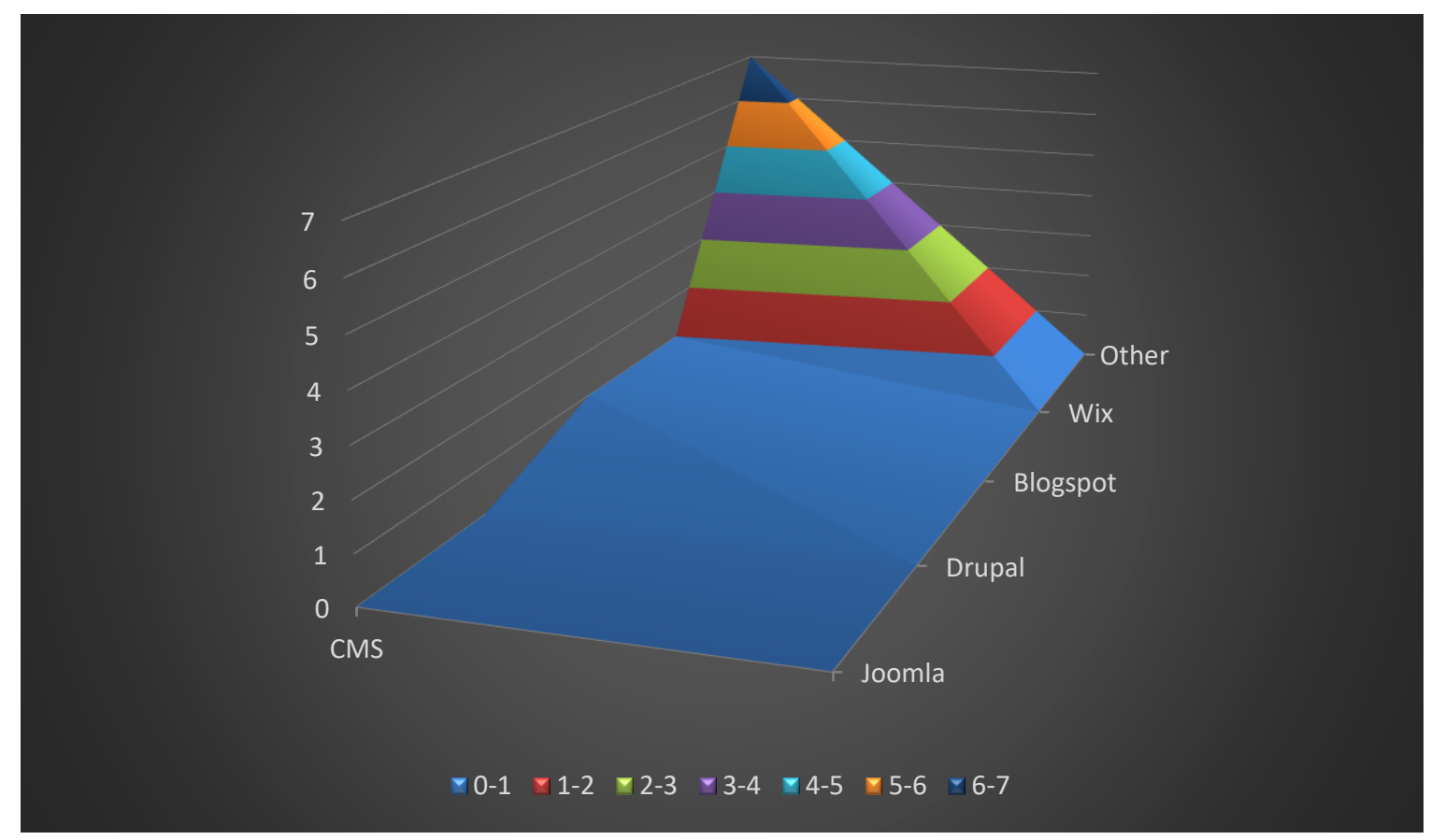

Figure 3: Usage of Content Management System

CMS: Table 4 \& Figure 3 shows the number of college library who used to develop the website using Content Management System (CMS). A content management system (CMS) is a software application or set of related programs that are used to create and manage digital content. A content management system (CMS) manages the creation and modification of digital content. It typically supports multiple users in a collaborative environment. CMS include Web based publishing, format management, history editing and version control, indexing search, and retrieval. Wix is a cloud-based web development platform. It allows users to create HTML5 websites and mobile sites through the use of online drag and drop tools. One college use Blogspot and one is use Wix to develop the library website both are the cloud hosting website. It is very easy to develop and update the information. 
Table 5: Access to digital library and Institutional repository

\begin{tabular}{|c|c|c|c|}
\hline \multirow[t]{2}{*}{ Sl. No } & \multirow[t]{2}{*}{ Libraries of the Colleges } & \multicolumn{2}{|c|}{ Digital Library and Institutional Repository } \\
\hline & & Yes & No \\
\hline 1 & Madhabdev College & $\checkmark$ & \\
\hline 2 & Dhakuakhana College & $\checkmark$ & \\
\hline 3 & Dhemaji College & $\checkmark$ & \\
\hline 4 & Lakhimpur Kendriya Mahavidayalaya & $\checkmark$ & \\
\hline 5 & Moridhal College & & $\checkmark$ \\
\hline 6 & Gogamukh College & $\checkmark$ & \\
\hline 7 & Debraj Roy College & $\checkmark$ & \\
\hline 8 & Maskhowa Degree College & & $\checkmark$ \\
\hline 9 & Dhemaji Commerce College & & $\checkmark$ \\
\hline 10 & M.D.K.G. College & $\checkmark$ & \\
\hline 11 & Dibru College & $\checkmark$ & \\
\hline 12 & North Lakhimpur College (Autonomous) & & $\checkmark$ \\
\hline
\end{tabular}

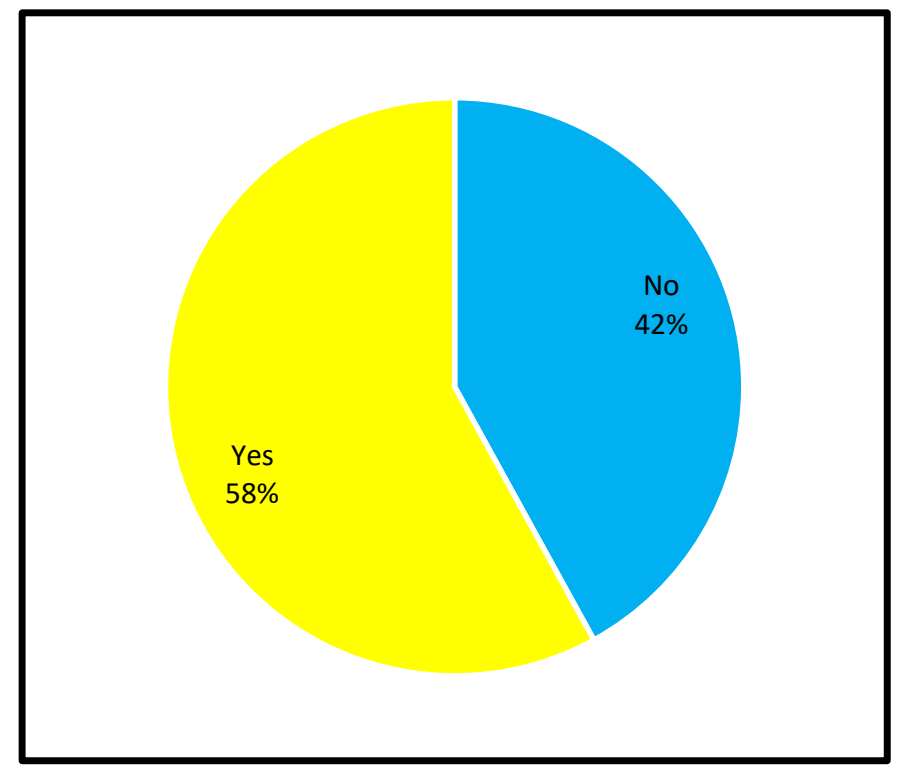

Digital Library/ IR : Figure 4 shows the $58 \%$ of college library website provide the link of their website or webpage to access the resources that in digital library or Institutional repository. User can access the digital library and institutional repository through the library website. Libraries provide a user name and password to access the digital library and it can be accessed only from college campus.

Figure 4: Access to digital library/ Institutional repository 


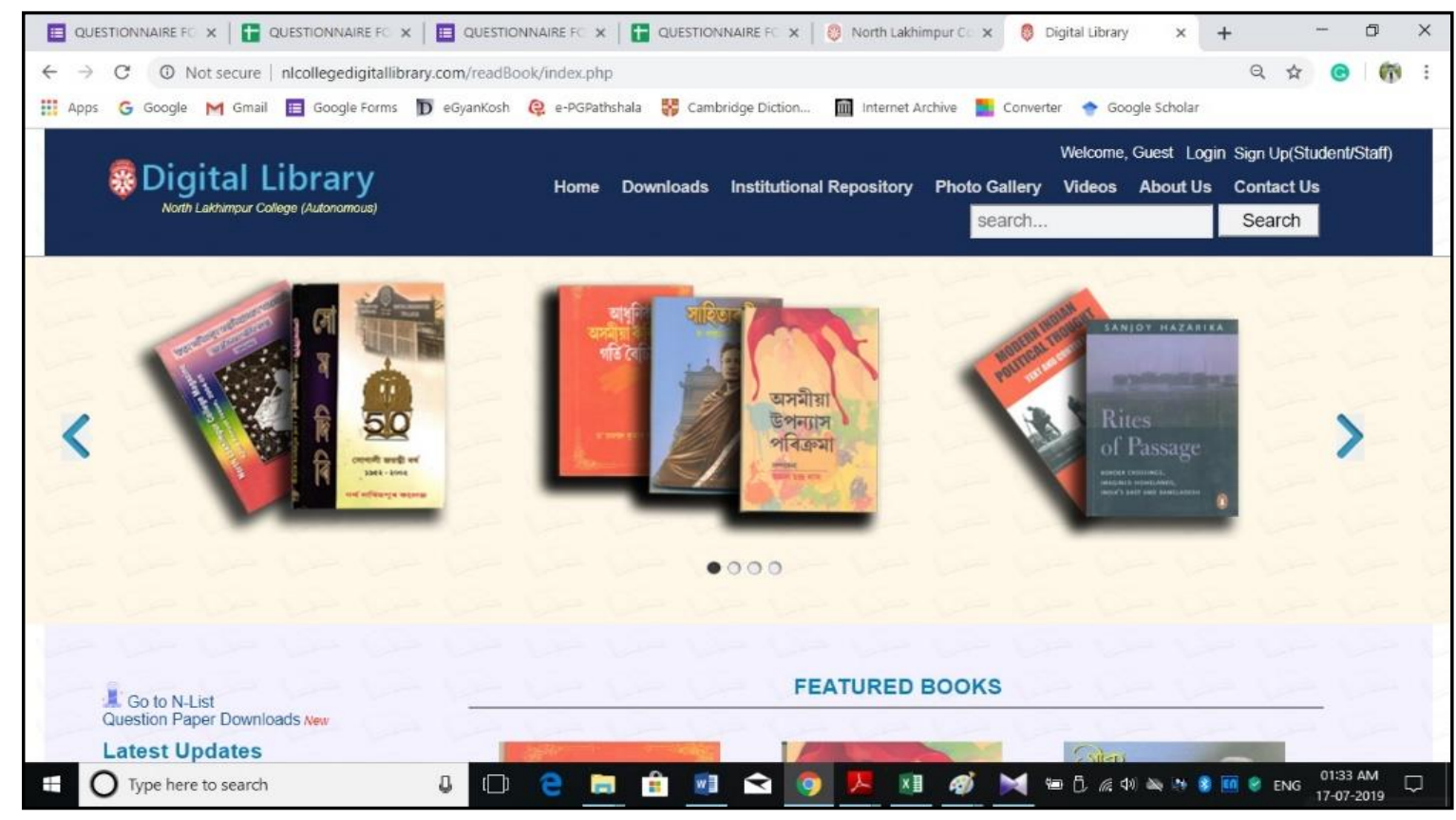

Figure 5: North Lakhimpur College (Autonomous) Digital Library website

(Source: http://nlcollegedigitallibrary.com/readBook/index.php)

North Lakhimpur College (Autonomous) Library provide username and password to access the digital library collections. $42 \%$ college libraries don't have digital library or institutional repository. However, they take initiative to develop IR for their college library.

Library website provides various links to access the e-resources which the library purchased. N-list is the main source of e-resource of the college library. The survey reveals the total 12 colleges are using $\mathrm{N}$-list to provide various types of e-resources for the college students.

Table 6: Latest Arrivals in the library

\begin{tabular}{|l|l|c|c|}
\hline \multicolumn{1}{|c|}{$\begin{array}{c}\text { Sl. } \\
\text { No }\end{array}$} & \multicolumn{1}{|c|}{ Libraries of the Colleges } & \multicolumn{2}{c|}{$\begin{array}{c}\text { Displaying latest arrivals in } \\
\text { Website }\end{array}$} \\
\cline { 3 - 4 } & & Yes & No \\
\hline $\mathbf{1}$ & Madhabdev College & $\checkmark$ & \\
\hline $\mathbf{2}$ & Dhakuakhana College & $\checkmark$ & \\
\hline $\mathbf{3}$ & Dhemaji College & $\checkmark$ & \\
\hline
\end{tabular}




\begin{tabular}{|l|l|c|c|}
\hline $\mathbf{4}$ & Lakhimpur Kendriya Mahavidayalaya & $\checkmark$ & $\checkmark$ \\
\hline $\mathbf{5}$ & Moridhal College & & $\checkmark$ \\
\hline $\mathbf{6}$ & Gogamukh College & $\checkmark$ & $\checkmark$ \\
\hline $\mathbf{7}$ & Debraj Roy College & & $\checkmark$ \\
\hline $\mathbf{8}$ & Maskhowa Degree College & & \\
\hline $\mathbf{9}$ & Dhemaji Commerce College & $\checkmark$ & \\
\hline $\mathbf{1 0}$ & M.D.K.G. College & $\checkmark$ & \\
\hline $\mathbf{1 1}$ & Dibru College & $\checkmark$ & \\
\hline $\mathbf{1 2}$ & North Lakhimpur College (Autonomous) & & \\
\hline
\end{tabular}

Displaying of the latest arrivals: Table 6 shows that $8(67 \%)$ of college library provide latest information in college library website. Latest information makes the user aware to new arrivals in the library. User can access the information through the library website. But $4(33 \%)$ of college library website does not provide latest information about the library. The main reason is that they have not a library website separately; they use the webpage of the library in the college website.

Table 7: Usages of Open Access Resources

\begin{tabular}{|l|l|c|c|}
\hline \multicolumn{1}{|c|}{ Sl. No } & \multicolumn{1}{|c|}{ Name of the College } & \multicolumn{2}{c|}{ Providing open access content } \\
\cline { 3 - 4 } & & Yes & No \\
\hline $\mathbf{1}$ & Madhabdev College & $\checkmark$ & \\
\hline $\mathbf{2}$ & Dhakuakhana College & $\checkmark$ & \\
\hline $\mathbf{3}$ & Dhemaji College & & \\
\hline $\mathbf{4}$ & Lakhimpur Kendriya Mahavidayalaya & $\checkmark$ & \\
\hline $\mathbf{5}$ & Moridhal College & & \\
\hline $\mathbf{6}$ & Gogamukh College & & \\
\hline $\mathbf{7}$ & Debraj Roy College & & $\checkmark$ \\
\hline
\end{tabular}




\begin{tabular}{|l|l|c|c|}
\hline $\mathbf{8}$ & Maskhowa Degree College & & $\checkmark$ \\
\hline $\mathbf{9}$ & Dhemaji Commerce College & & \\
\hline $\mathbf{1 0}$ & M.D.K.G. College & $\checkmark$ & \\
\hline $\mathbf{1 1}$ & Dibru College & $\checkmark$ & \\
\hline $\mathbf{1 2}$ & North Lakhimpur College (Autonomous) & $\checkmark$ & \\
\hline
\end{tabular}

Table 7 shows that $67 \%$ of college library website provide various types of free/open access resource links. Several library provide National Digital Library link, NCERT free text book link, Google books, Internet Archive and various type of online free access resources. But $33 \%$ of college library does not provide the open access resource link because they have not a website to provide this type of information.

Figure 6: Frequency of real time service

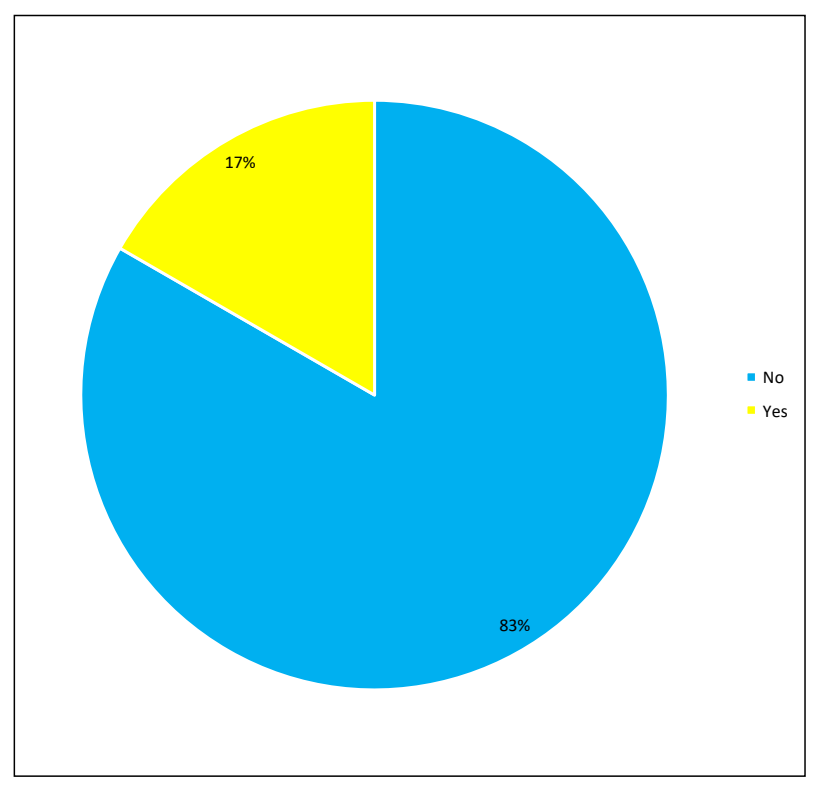

Figure 6 is an illustration of the real time service provided in the library website. Only $17 \%$ of the college library website provides the real time service. They use online chatting facility in their website and social media to communicate the library user. But $83 \%$ of college library website does not provide the real time services.

Table 8 : Online Library membership

\begin{tabular}{|l|c|c|}
\hline \multirow{2}{*}{\multicolumn{1}{c|}{ Name of the college }} & \multicolumn{2}{c|}{ Library Membership } \\
\cline { 2 - 3 } & \multicolumn{1}{c|}{ Yes } & No \\
\hline Madhabdev College & $\checkmark$ & $\checkmark$ \\
\hline Dhakuakhana College & & \\
\hline Dhemaji College & $\checkmark$ & \\
\hline
\end{tabular}




\begin{tabular}{|l|c|c|}
\hline $\begin{array}{l}\text { Lakhimpur Kendriya } \\
\text { Mahavidayalaya }\end{array}$ & $\checkmark$ \\
\hline Moridhal College & $\checkmark$ \\
\hline Gogamukh College & $\checkmark$ \\
\hline Debraj Roy College & $\checkmark$ & $\checkmark$ \\
\hline Maskhowa Degree College & $\checkmark$ & \\
\hline Dhemaji Commerce College & & $\checkmark$ \\
\hline $\begin{array}{l}\text { M. D. K. G. College } \\
\text { Dibru College }\end{array}$ & $\checkmark$ \\
\hline $\begin{array}{l}\text { North Lakhimpur College } \\
\text { (Autonomous) }\end{array}$ & & $\checkmark$ \\
\hline
\end{tabular}

Table 8 shows that online library membership forms facility provided in only $25 \%$ of college library website. MDKG Girls college library provide membership form through the Google forms. It reduces the staff work and provides a fast service to the users of the library. $75 \%$ of college library use manual forms for membership for user enrolment. They provide forms and user can submit with required documents in the library and librarian issues a library card following the library rules. But in online forms it is very easy as it is a less time consuming process and it automatically update in the library database .College library website can also provide the subject gateway to access the information in a particular subject area. Madhavdev College and North Lakhimpur College (Autonomous) Library use various subject gateway to provide subject wise information about the particular subject area. Student can access the information through the website at anytime and anywhere as per his convenience.

Table 9: Ask a Librarian service

\begin{tabular}{|l|l|c|c|}
\hline \multirow{2}{*}{ SL. No } & \multicolumn{1}{|c|}{ Name of the college } & Use of Ask a Librarian \\
\cline { 3 - 4 } & & Yes & No \\
\hline $\mathbf{1}$ & Madhabdev & $\checkmark$ & $\checkmark$ \\
\hline $\mathbf{2}$ & Dhakuakhana College & & $\checkmark$ \\
\hline $\mathbf{3}$ & Dhemaji College & & $\checkmark$ \\
\hline $\mathbf{4}$ & Lakhimpur Kendriya Mahavidayalaya & & \\
\hline
\end{tabular}




\begin{tabular}{|l|l|c|c|}
\hline $\mathbf{5}$ & Moridhal College & $\checkmark$ & $\checkmark$ \\
\hline $\mathbf{6}$ & Gogamukh College & & $\checkmark$ \\
\hline $\mathbf{7}$ & Debraj Roy College & & $\checkmark$ \\
\hline $\mathbf{8}$ & Maskhowa Degree College & & $\checkmark$ \\
\hline $\mathbf{9}$ & Dhemaji Commerce College & & \\
\hline $\mathbf{1 0}$ & M. D. K. G. College & $\checkmark$ & $\checkmark$ \\
\hline $\mathbf{1 1}$ & Dibru College & & \\
\hline $\mathbf{1 2}$ & North Lakhimpur College (Autonomous)) & $\checkmark$ & \\
\hline
\end{tabular}

Table 9 display that only $4(33 \%)$ college library website provide ask a librarian service to their users. Ask a librarian is an online reference service which provided in real time to the user. It helps to refer a user to a dedicated way of information accessing. But $67 \%$ of college library website could not provide ask a librarian service. It's a weak point of these college libraries.

For providing ask a librarian service, the library use email, online chatting, and social media. But user response is not satisfactory. Some college library provides digital reference service to the user. Library provides digital reference service through the digital media and tools. Email is basically used to communicate with the user.

Figure 7: Statistics of Library website hits 


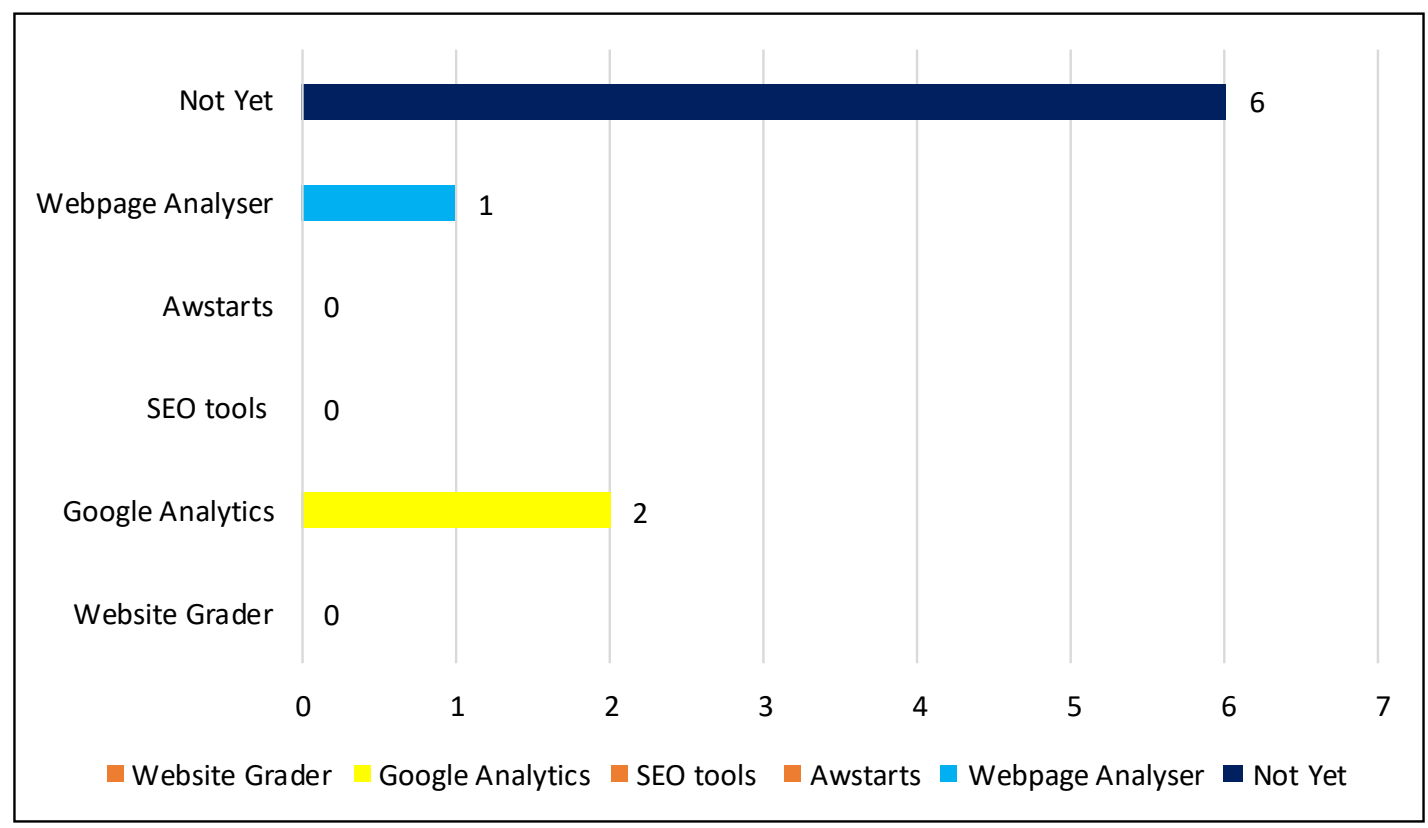

Figure 7 shows the web analyser statistics to maintain and review the usages of the library website by the user. The figure reflect that most of the libraries website doesn't use any web analyser to measure the statistics. Only two (2) colleges use Google analytics and one college use webpage analyser to measure the statistics ; out of 12 surveyed libraries.

\section{CONCLUSION}

The changing paradigm of Library \& Information landscape postures a bulk of avenues in dissemination of information. Library website can act as a catalyst agent in this respect. It is evident from the study that web based facilities in the college libraries of Assam is in initial stage. Poor ICT infrastructure, lack of trained manpower in the respective domain and fund crunch seems to be the main reason behind the scene.

\section{REFERENCES}

1. Kaushik, A.(2015).An Evaluation of National Institutes of Technology (NITs) Library Websites. DESIDOC Journal of Library and Information Technology, 35(3), 223234.DOI: 10.14429/djlit.35.3.8721.

2. Kaur, K. \& Singh, D.(2010).Customer service for academic library users on the web. The Electronic Library, 29 (6), 737-750.DOI:10.1108/026471111187971. 
3. Konnur, P.V, Rajani, S. \& Madhusudhan , M.(2010).Academic Library Websites in Bangalore City, India: An Evaluative Study, Library Philosophy and Practice ( ejournal).408. Retrieved from http://digitalcommons.unl.edu.libphilprac/408.

4. Kumar, R.R. (2017). Marketing Electronic Information Resources ( EIRs) in Academic libraries : A Conceptual study, International Journal of Library and Information Studies,7(4),217-226. Retrieved from http://www.ijlis.org.

5. Manjunath, K.S.(2016). Content Analysis of special library websites: An Analytical study, International Journal of Next Generation Library and Technologies,2(2),19.Retrieved from https://www.ijnglt.com.

6. Pareek, S. \& Gupta, K.D.(2012).Information about services and Information Resources on websites of selected Libraries in Rajasthan : A study, DESIDOC Journal of Library and Information Technology,32(6),499-508.Retrieved from https://publications.drdo.gov.in>ojs>djlit.

7. Shukla, A \& Tripathi, A. ( 2010).Establishing Content Awareness evaluation criteria: a case study, Annals of Library and Information Studies, 57(4),403-416.Retrieved from nopr.niscair.res.in. 